\title{
COATING SEEDS WITH SILICON ENHANCES THE CORN YIELD OF THE SECOND CROP ${ }^{1}$
}

\author{
LENNIS AFRAIRE RODRIGUES ${ }^{2}$, IZABELA CRISTINA DE OLIVEIRA ${ }^{2}$, GRAZIELY ALVES NOGUEIRA ${ }^{2}$, TIAGO \\ ROQUE BENETOLI DA SILVA ${ }^{3}$, ANA CARINA DA SILVA CANDIDO ${ }^{2}$, CHARLINE ZARATIN ALVES $^{2 *}$
}

\begin{abstract}
The application of silicon is becoming popular in agriculture as an alternative for integrated crop management, owing to the diverse benefits resulting from the accumulation of silicon in grasses and the resultant resistance conferred in plants against biotic and abiotic stresses. The objective of this study was to evaluate whether the application of silicon, via seed coating and leaf application, influences the production and yield components of maize in the second crop. The experimental design was divided into split plots, in which the plots were composed of phyllosilicate doses $\left(0,5,10,15\right.$, and $20 \mathrm{~g} \mathrm{~kg}^{-1}$ of seeds) in the seed coatings and the subplots were composed of foliar applications of potassium silicate (1.0 $\mathrm{L} \mathrm{ha}^{-1}$ in pre-dip and 15 days after). We evaluated the plant height, spike insertion height, spike and corncob diameter, number of rows per spike, number of grains per row, the mass of 100 grains, and productivity. The foliar application of potassium silicate had no effect on the yield and yield components of the corn crop. The use of phyllosilicate via seed coating increased the production components and yield of the second corn crop.
\end{abstract}

Keywords: Zea mays. Silicate. Silicate fertilization.

\section{RECOBRIMENTO DE SEMENTES COM SILÍCIO AUMENTA A PRODUTIVIDADE DE MILHO DE SEGUNDA SAFRA}

\begin{abstract}
RESUMO - A aplicação de silício está sendo difundida na agricultura como alternativa a ser integrada no manejo das culturas, por conta dos diversos benefícios relatados nas gramíneas acumuladoras e na resistência à estresses bióticos e abióticos. Assim, objetivou se avaliar a aplicação de silício via recobrimento de sementes e foliar nos componentes de produção do milho segunda safrinha. O delineamento experimental utilizado foi em

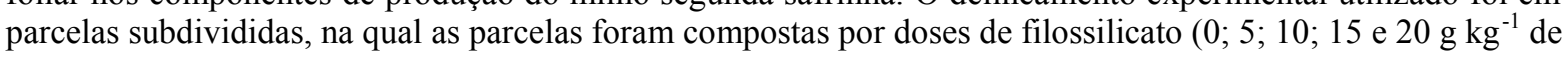
sementes) no recobrimento de sementes, e as subparcelas constituídas pela aplicação foliar de silicato de potássio (1,0 L ha ${ }^{-1}$ em pré-pendão e 15 dias após). As avaliações realizadas foram: altura de plantas, altura de inserção de espiga, diâmetro de espiga e sabugo, número de fileiras por espiga, número de grãos por fileira, massa de 100 grãos e produtividade. Não houve efeito da aplicação foliar de silicato de potássio na produtividade e componentes de produção do milho safrinha. $\mathrm{O}$ uso de filossilicato via recobrimento de sementes incrementou os componentes de produção e a produtividade do milho safrinha segunda safra.
\end{abstract}

Palavras-chave: Zea mays. Silicato. Adubação silicatada.

\footnotetext{
${ }^{*}$ Corresponding author

${ }^{1}$ Received for publication in $07 / 15 / 2019$; accepted in $10 / 16 / 2019$.

Paper extracted from the master's dissertation of the first author.

${ }^{2}$ Department of Agronomy, Universidade Federal de Mato Grosso do Sul, Chapadão do Sul, MS, Brazil; lennisrodrigues@gmail.com ORCID: 0000-0003-1509-3775, izabelamarangon@gmail.com - ORCID: 0000-0002-4666-801X, graziely.nogueira@hotmail.com ORCID: 0000-0001-6985-3317, ana.candido@ufms.br - ORCID: 0000-0002-9230-4807, charline.alves@ufms.br - ORCID: 0000-00016228-078X.

${ }^{3}$ Department of Science Agronomic, Universidade Estadual de Maringá, Umuarama, PR, Brazil; trbsilva@uem.br - ORCID: 0000-00022015-2103.
} 


\section{INTRODUCTION}

Silicon is not considered an essential element for plant growth. However, there are several studies that highlight the beneficial effects that the availability of this element can bring. These benefits include: increased lodging resistance and photosynthetic efficiency; contributions to the physical functions of evapotranspiration regulations in corn (SOUSA; KORNDÖRFER; WANGEN, 2010); increased absorption and metabolism of elements, e.g., phosphorus; decrease in the toxic effects of iron, manganese, aluminum, sodium, and heavy metals (SHI et al., 2005) in the crop; mechanical resistance to the invasion of phytopathogenic microorganisms and insect pests (COSTA; MORAES; COSTA, 2009); and an increase in seed quality of sweet sorghum (LESSA et al., 2017).

The main effect of the availability of silicon on plants is the mechanical protection attributed mainly to the deposition of amorphous silica $\left(\mathrm{SiO}_{2} \cdot \mathrm{nH}_{2} \mathrm{O}\right)$ on cell walls (MENDES; SOUZA; MACHADO, 2011). This element accumulates in the organs of greater perspiration, causing the formation of a double layer of cuticular silica, which, by reducing the loss of water to the atmosphere, causes the water requirement of the plants to be lower (MA; YAMAJI, 2006). Thus, silicon is a viable tool to be used under limiting conditions, mainly in the accumulation of this element in grasses, as well as sugarcane and rice, in which productivity gains have been observed with the adoption of silicate fertilization (MENDES; SOUZA; MACHADO, 2011). The second corn crop is exposed to water stress conditions, which must be physiologically overcome to ensure a high productivity through good development during the reproductive phase.

The supply of silicon can be done via the soil surface, embedded in the soil using sowing furrows, and via seed coating and foliar applications. The choice of the application method depends upon the source product of the element and the moment of application. The main sources of silicon used on Brazilian crops are calcium and magnesium silicates from steel slag, since they are the cheapest and most abundant sources of silicates (STOCCO et al., 2010). In addition to presenting low levels of soluble silicon, they are also insoluble or have low solubility in water, have heavy metals in their constitution, and can alter soil pH (NOGUEIRA et al., 2012).
Silicon is not very mobile inside plants (PEREIRA et al., 2007); so, the supply through seed coating and foliar application guarantees that the element is readily available during germination and establishment and in the reproductive phase of the culture. It is known that monocotyledon species respond well to silicate fertilization and that these plants have the capacity to accumulate this mineral in leaf and stem tissues (SOUSA et al., 2013). There are some studies that have already verified the positive effects of silicon on some maize production and productivity components, such as Teodoro et al. (2014), who observed an increase in the ear length through the foliar application of silicon in different hybrids. Sousa et al. (2010) also attributed increases in the mass of a thousand grains and yield of maize to silicon. However, these studies emphasize the diversification of responses in relation to the intensity of stresses to which the crop is submitted.

Therefore, this work aimed to evaluate the effects of the application of silicon via seed coating and foliar application on the components of corn production in the second crop.

\section{MATERIAL AND METHODS}

The work was carried out in the experimental area of the Chapadão Foundation for Agricultural Research Support (Chapadão Foundation), located in the municipality of Chapadão do Sul, in the state of Mato Grosso do Sul (MS), Brazil (18 41'33"S, 52 ${ }^{\circ}$ $40^{\prime} 45^{\prime \prime} \mathrm{W}$, and average altitude of $810 \mathrm{~m}$ ). The predominant soil class is Dystrophic Red Latosol and the climate is, according to Köppen, of the tropical humid type (Aw), presenting a rainy season in the summer and dry season in the winter, with an average annual precipitation of $1850 \mathrm{~mm}$ (Figure 1).

The chemical attributes of the soil, macronutrient contents, and grain size at a depth of 0 $-20 \mathrm{~cm}$ are shown in Table 1. The sowing was carried out in February 2014 using AG 8544 PRO2 transgenic simple hybrid corn seeds, in a system of direct seeding on Urochloa decumbens crop residues, with a seven row vacuum seeder. In the basal fertilization, $154 \mathrm{~kg} \mathrm{ha}^{-1}$ of monoammonium phosphate or MAP $\left(10 \% \mathrm{~N}\right.$ and $\left.46-50 \% \mathrm{P}_{2} \mathrm{O}_{5}\right)$ and $100 \mathrm{~kg} \mathrm{ha}^{-1}$ of urea were used during the V6 stage of the crop, highlighting the absence of potassium fertilization during sowing, after which foliar potassium silicate was applied. 


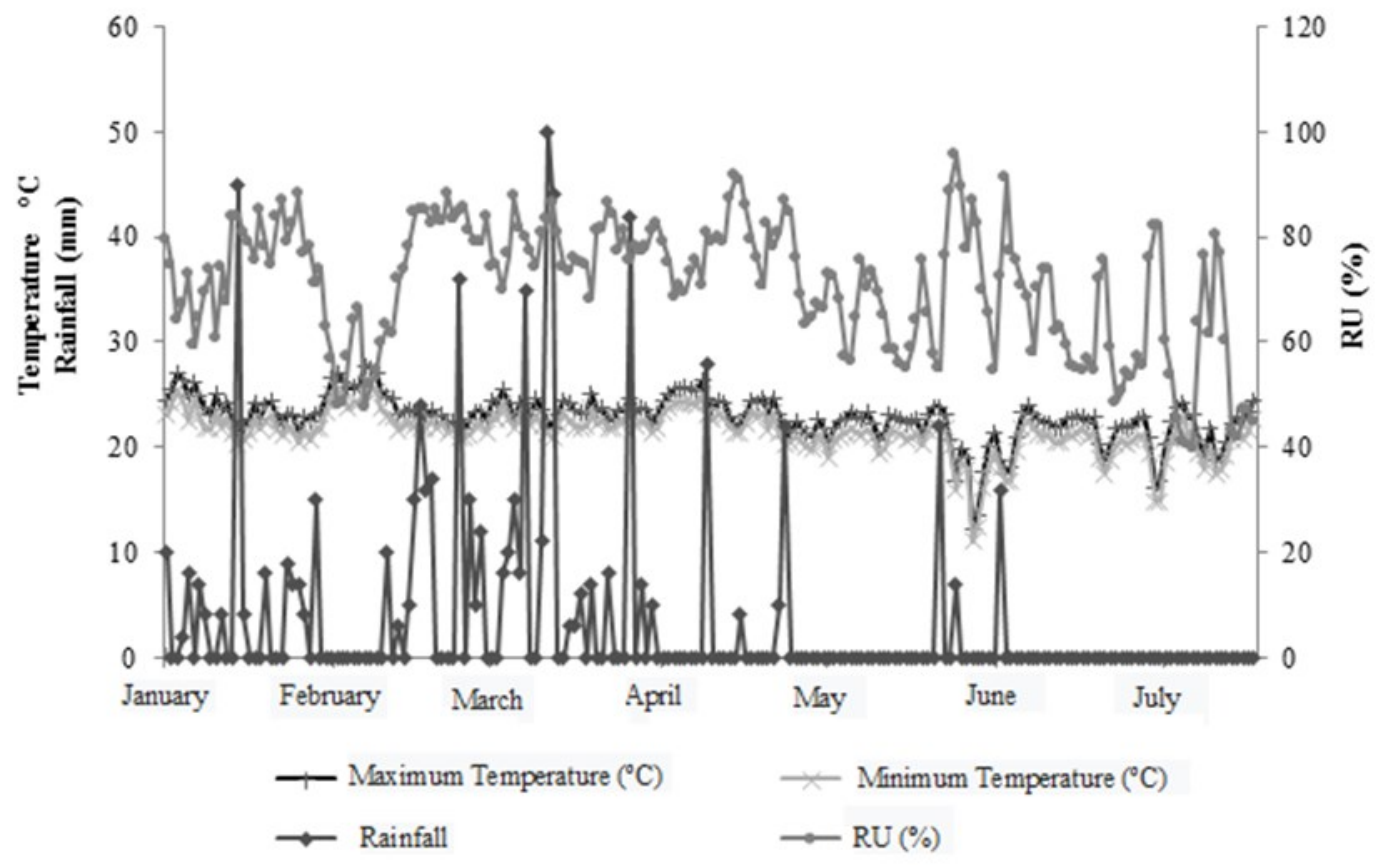

Figure 1. Daily rainfall, maximum and minimum temperatures, and relative humidity $(\mathrm{RH})$ during the experiment

Table 1. Chemical analysis of the soil of the experimental area in the 0 to $20 \mathrm{~cm}$ layer

\begin{tabular}{|c|c|c|c|c|c|c|c|}
\hline $\begin{array}{c}\mathrm{Ph} \\
\left(\mathrm{CaCl}_{2}\right) \\
\end{array}$ & $\begin{array}{c}\mathrm{Ca} \\
\left(\mathrm{cmolc} \mathrm{dm}^{-3}\right) \\
\end{array}$ & $\begin{array}{c}\mathrm{Mg} \\
\left(\mathrm{cmolc} \mathrm{dm}^{-3}\right) \\
\end{array}$ & $\begin{array}{c}\mathrm{Al} \\
\left(\mathrm{cmolc} \mathrm{dm}^{-3}\right) \\
\end{array}$ & $\begin{array}{c}\mathrm{H}+\mathrm{Al} \\
\left(\mathrm{cmolc} \mathrm{dm}^{-3}\right)\end{array}$ & $\begin{array}{c}\mathrm{K} \\
\left(\mathrm{cmolc} \mathrm{dm}^{-3}\right) \\
\end{array}$ & $\begin{array}{c}\mathrm{P} \\
\left(\mathrm{mg} \mathrm{dm}^{-3}\right) \\
\end{array}$ & $\begin{array}{c}\mathrm{S} \\
\left(\mathrm{mg} \mathrm{dm}^{-3}\right)\end{array}$ \\
\hline 4.80 & 2.50 & 0.60 & 0.22 & 2.90 & 0.19 & 10.60 & 5.00 \\
\hline $\begin{array}{c}\text { CEC } \\
\left(\mathrm{cmolc} \mathrm{dm}^{-3}\right) \\
\end{array}$ & BS (\%) & Sat. Al (\%) & $\begin{array}{c}\mathrm{B} \\
\left(\mathrm{mg} \mathrm{dm}^{-3}\right) \\
\end{array}$ & $\begin{array}{c}\mathrm{Cu} \\
\left(\mathrm{mg} \mathrm{dm}^{-3}\right) \\
\end{array}$ & $\begin{array}{c}\mathrm{Fe} \\
\left(\mathrm{mg} \mathrm{dm}^{-3}\right)\end{array}$ & $\begin{array}{c}\mathrm{Mn} \\
\left(\mathrm{mg} \mathrm{dm}^{-3}\right) \\
\end{array}$ & $\begin{array}{c}\mathrm{Zn} \\
\left(\mathrm{mg} \mathrm{dm}^{-3}\right) \\
\end{array}$ \\
\hline 6.19 & 53.20 & 6.30 & 0.20 & 1.40 & 67.00 & 18.50 & 7. 60 \\
\hline \multicolumn{2}{|c|}{$\mathrm{OM}\left(\mathrm{g} \mathrm{dm}^{-3}\right)$} & \multicolumn{2}{|c|}{ Clay $\left(\mathrm{g} \mathrm{dm}^{-3}\right)$} & \multicolumn{2}{|c|}{ Silte $\left(\mathrm{g} \mathrm{dm}^{-3}\right)$} & \multicolumn{2}{|c|}{ Sand $\left(\mathrm{g} \mathrm{dm}^{-3}\right)$} \\
\hline \multicolumn{2}{|c|}{29.10} & \multicolumn{2}{|c|}{635.00} & \multicolumn{2}{|c|}{50.00} & \multicolumn{2}{|c|}{315.00} \\
\hline
\end{tabular}

BS - Base Saturation; CEC - Cation Exchange Capacity; Sat. Al - Saturation of Aluminum; OM - Organic matter

The experiment was carried out in subdivided plots, wherein each plot consisted of five doses of filossilicate $(26.68 \% \mathrm{Si}, 3 \% \mathrm{CaO}$, and $1.6 \% \mathrm{MgO}$; trade name Microton), by coating seeds at the doses $0,5,10,15$, and $20 \mathrm{~g} \mathrm{~kg}^{-1}$ of seeds. The subplots were characterized by the presence or absence of foliar application of potassium silicate $(12.2 \% \mathrm{Si}$ and $15.8 \% \quad \mathrm{~K}_{2} \mathrm{O}$; trade name Sifol) at the dosage $1.0 \mathrm{~L} \mathrm{ha}^{-1}$ on pre-corn tassel 15 days after the first application, with four replicates.

The seed coating was performed with the use of an electric mixer, for the better adhesion of seeds. For this, water at the proportion of $10 \mathrm{~mL} \mathrm{~kg}^{-1}$ of seeds was added. The foliar applications of potassium silicate were carried out using a constant pressure costal sprayer $\left(\mathrm{CO}_{2}\right)$, equipped with a $3.0 \mathrm{~m}$ bar with six fan jet tips, spaced $50 \mathrm{~cm}$ apart, with a volume of $150 \mathrm{~L} \mathrm{ha}^{-1}$, and pressure of 3.0 bar. Each experimental plot consisted of seven lines that were $5.5 \mathrm{~m}$ in length, with $0.45 \mathrm{~m}$ spacings between rows, and a density of three seeds per meter. The evaluations were carried out in four meters of the three central lines, making a useful area of $5.4 \mathrm{~m}^{2}$.

Prior to corn sowing, Urochloa decumbens was desiccated, using glyphosate at a dose of $1.5 \mathrm{~kg}$ $\mathrm{ha}^{-1}$, and two applications of atrazine $\left(1.5 \mathrm{~kg} \mathrm{ha}^{-1}\right)$ were used at 20 and 45 days after emergence. The other phytosanitary treatments used to control pests and diseases were: Imidacloprid + Beta-Cyfluthrin $\left(10+1.25 \mathrm{~g} \mathrm{ha}^{-1}\right)$ in the V2 stage; Novaluron $(15 \mathrm{~g}$ $\left.\mathrm{ha}^{-1}\right)$ and Metomil $\left(215 \mathrm{~g} \mathrm{ha}^{-1}\right)$ in the V4 stage; Novaluron $\left(15 \mathrm{~g} \mathrm{ha}^{-1}\right)$ in the V6 stage; and Triazole + Strobilurin $\left(25+66 \mathrm{~g} \mathrm{ha}^{-1}\right)$ in the R1 stage.

The evaluations carried out at the time of 
harvest were: plant height (from the lap to the point of insertion of the last expanded leaf) and spike insertion height, in ten random plants per plot using a graded wooden ruler. The measurements concerning the spike diameter and corncob diameter were performed with a digital caliper, using ten samples per plot. We also measured the number of rows per spike, number of grains per row, and mass of 100 grains, obtained through the manual counting of the grains and weighing using a semi-analytical balance. The manually harvested ears were threshed and the grain yield, corrected for $13 \%$ moisture, was obtained in kilos per hectare.

Data were subjected to an analysis of variance (ANOVA), using the $\mathrm{F}$ test at a $5 \%$ probability, in the statistical program SISVAR 5.3 (FERREIRA, 2010). For the quantitative factor (doses), a regression analysis was used. For the qualitative factor (application forms), only the F test was used.

\section{RESULTS AND DISCUSSION}

The results show that the interaction between the seed coating and foliar application of silicon was not significant (Table 2). In addition, the foliar application of silicon did not influence any of the evaluated variables. Thus, Silicon application may have the same benefit on plants irrespective of its way of application.

Positive results were only observed with the application of silicon through seed coating (Table 2). Similarly, Oliveira et al. (2016) concluded that the coating of rice seeds with different sources of silicon provided a more vigorous seed production.

Table 2. Spike insertion height (SIH), plant height (PH), spike diameter (SD), corncob diameter (CD), number of rows per spike (NRS), number of grains per row (NGR), mass of 100 grains (MG), and grain yield (Y) of maize as a function of silicon application via seed coating and foliar application.

\begin{tabular}{|c|c|c|c|c|c|c|c|c|}
\hline \multirow{2}{*}{$\begin{array}{c}\mathrm{SC} \\
\left(\mathrm{g} \mathrm{kg}^{-1} \text { of seeds }\right) \\
\end{array}$} & $\mathrm{SIH}$ & PH & SD & $\mathrm{CD}$ & \multirow{2}{*}{ NRS } & \multirow{2}{*}{ NGR } & \multirow{2}{*}{$\begin{array}{c}\mathrm{MG} \\
(\mathrm{g}) \\
\end{array}$} & \multirow{2}{*}{$\frac{\mathrm{Y}}{\left(\mathrm{kg} \mathrm{ha}^{-1}\right)}$} \\
\hline & \multicolumn{2}{|c|}{$(\mathrm{cm})$} & \multicolumn{2}{|c|}{$(\mathrm{mm})$} & & & & \\
\hline 0 & 113.1 & 221.0 & 45.0 & 27.1 & 16.4 & 31.2 & 22.6 & 5726.2 \\
\hline 5 & 111.6 & 225.1 & 49.2 & 30.4 & 18.6 & 34.3 & 24.2 & 7593.3 \\
\hline 10 & 110.9 & 224.4 & 49.4 & 30.5 & 18.6 & 32.5 & 23.8 & 7511.7 \\
\hline 15 & 113.6 & 227.0 & 48.1 & 29.7 & 18.7 & 34.5 & 24.4 & 7463.3 \\
\hline 20 & 114.6 & 223.6 & 48.6 & 30.3 & 18.3 & 33.8 & 24.2 & 8195.9 \\
\hline \multicolumn{9}{|l|}{ FA } \\
\hline Absent & 111.9 & 224.0 & 47.5 & 29.5 & 18.3 & 33.1 & 23.6 & 7285.7 \\
\hline Present & 112.6 & 224.5 & 48.2 & 29.7 & 17.9 & 33.8 & 24.1 & 7310.5 \\
\hline $\mathrm{F}(\mathrm{SC})$ & $0.89^{\text {ns }}$ & $2.92^{\mathrm{ns}}$ & $16.14^{*}$ & $10.48^{*}$ & $12.41 *$ & $5.02 *$ & $1.21^{\mathrm{ns}}$ & $18.38^{*}$ \\
\hline $\mathrm{F}(\mathrm{FA})$ & $0.03^{\mathrm{ns}}$ & $0.13^{\mathrm{ns}}$ & $2.55^{\mathrm{ns}}$ & $0.43^{\mathrm{ns}}$ & $1.43^{\mathrm{ns}}$ & $1.80^{\mathrm{ns}}$ & $0.56^{\mathrm{ns}}$ & $0.01^{\mathrm{ns}}$ \\
\hline $\mathrm{F}(\mathrm{ST} * \mathrm{FA})$ & $0.08^{\mathrm{ns}}$ & $0.14^{\mathrm{ns}}$ & $1.24^{\mathrm{ns}}$ & $0.59^{\mathrm{ns}}$ & $0.35^{\mathrm{ns}}$ & $0.65^{\mathrm{ns}}$ & $1.06^{\mathrm{ns}}$ & $1.40^{\mathrm{ns}}$ \\
\hline $\mathrm{CV}(\%) \mathrm{SC}$ & 4.02 & 1.62 & 3.23 & 4.24 & 4.39 & 4.94 & 7.74 & 8.38 \\
\hline CV (\%) FA & 4.40 & 1.73 & 2.52 & 3.77 & 3.79 & 4.58 & 6.40 & 11.10 \\
\hline
\end{tabular}

The doses of silicon applied via seed coating influenced the diameter of the spike and corncob (Table 2). The data were adjusted using quadratic equations, in which the maximum point was observed at the doses of 12.46 and $13.22 \mathrm{~g} \mathrm{~kg}^{-1}$ of seeds, respectively (Figure $2 \mathrm{~A}$ and $2 \mathrm{~B}$ ). For the number of rows per spike, there was an increase up to the dose of $12.83 \mathrm{~g} \mathrm{~kg}^{-1}$ of seeds, after which the number of rows decreased (Figure 2C). 

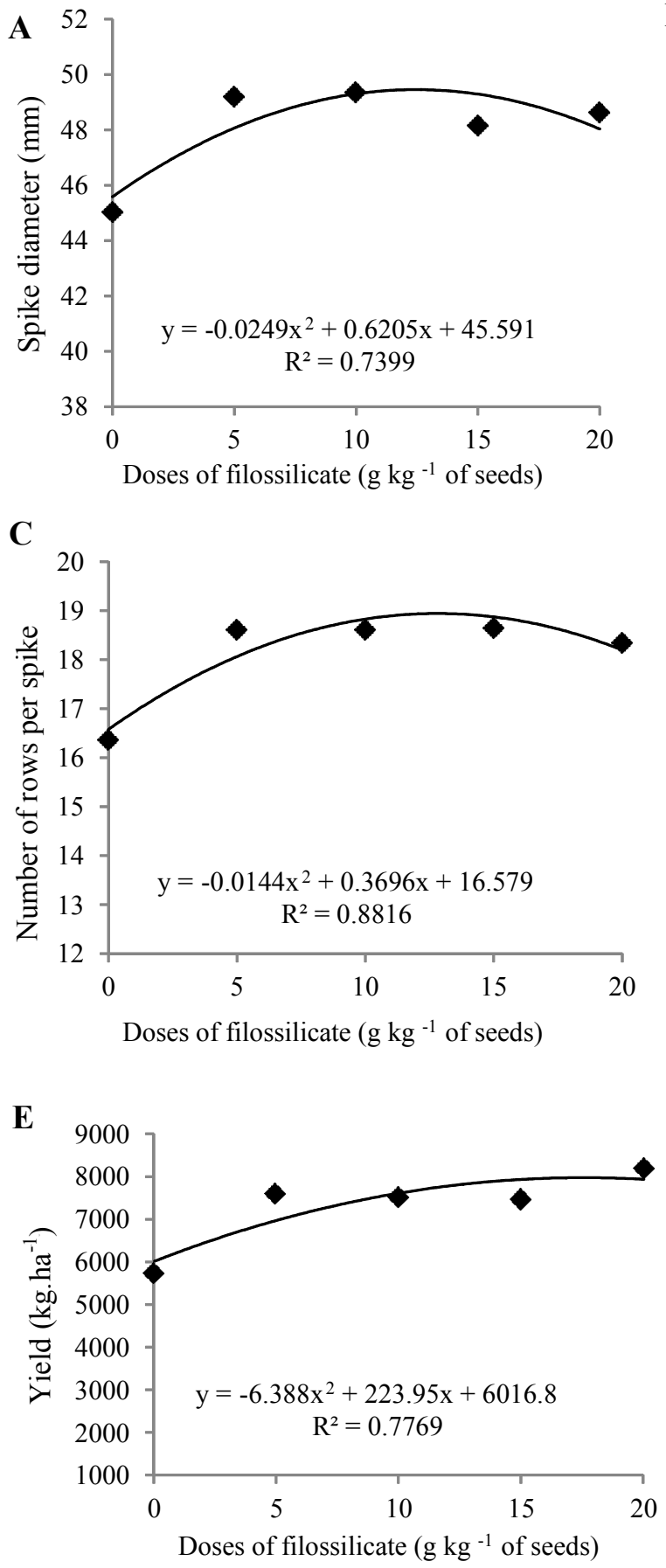

B
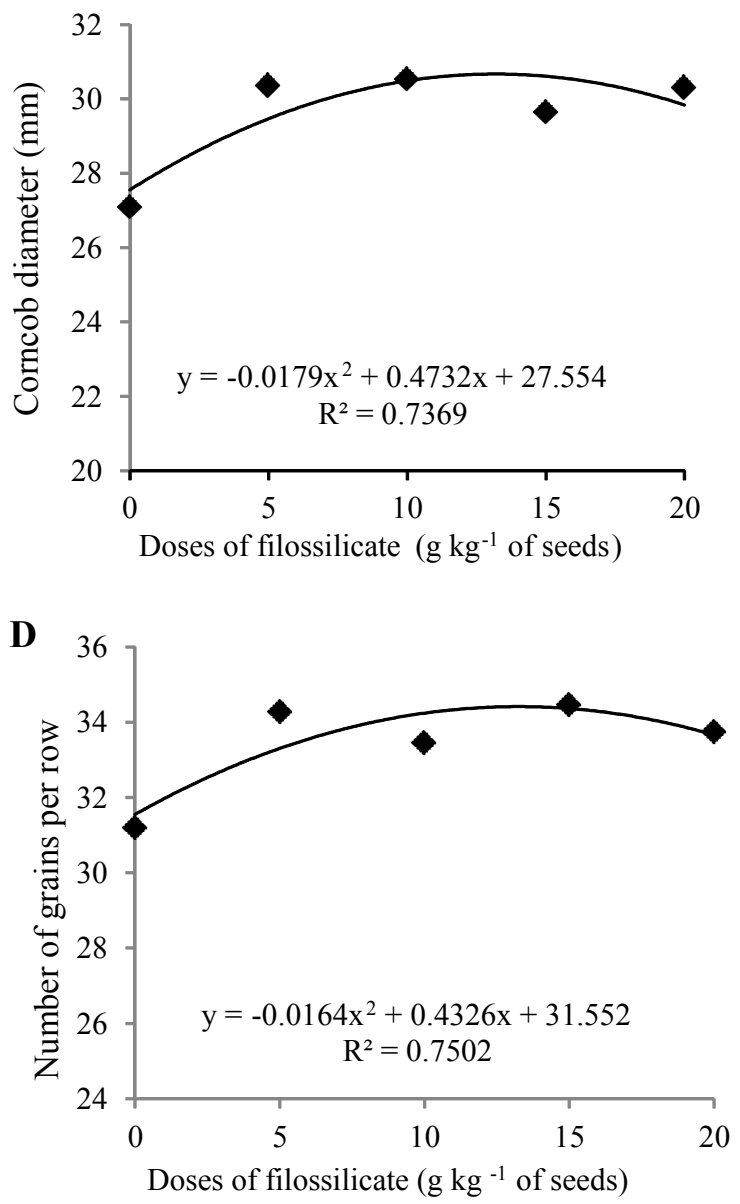

Figure 2. Spike diameter (A), corncob diameter (B), number of rows per spike (C), number of grains per row (D), and yield (E) of maize as a function of the doses of filossilicate used for seed coating

The number of grains per row was influenced by the silicon doses via seed coating (Table 2), responding positively up to the estimated dose of $13.19 \mathrm{~g} \mathrm{~kg}^{-1}$ of seeds (Figure 2D). The number of grains per row is an important indicator for good spike formation contributing to the increase of maize productivity, as it directly reflects the number of grains per spike. This parameter is related to the spike and corncob diameter, as the diameter growth of the newly formed spikes pre-determines the number of eggs that have the capacity to fertilize and become grains.

The positive results for the production components reflect the effects of silicon as a source of biotic and abiotic stresses (COSKUN et al., 2016), since this element is believed to be involved in metabolic and physiological plant activities, which indirectly effects plants photosynthetically and 
contributes to the formation of reproductive structures. Gunes et al. (2008) verified this when working with sunflowers, as the application of silicon led to the accumulation of antioxidant enzymes, greater photosynthetic activity, and an increase in productivity.

The mass of 100 grains was not affected by the silicon applied to the seed. This aligns with Teodoro et al. (2014) and Freitas et al. (2011), who concluded that foliar applications of silicon from active silica and potassium silicate sources, respectively, in various hybrids and at different times of the year, did not affect the mass of 100 corn grains. The grain yield responded in a quadratic manner to the silicon doses via seed coating (Figure 2E), obtaining a maximum point at $17.53 \mathrm{~g} \mathrm{~kg}^{-1}$ of seeds. Dantas Júnior et al. (2013), also studying doses of calcium and magnesium silicate, obtained quadratic responses from the stem and leaf dry matter, with a maximum dose of $164 \mathrm{~g}$ per pot of 80 $\mathrm{kg}$ of soil

Mendes, Souza and Machado (2011) stated that productivity responses to silicate fertilization may be related to stress resistance. However, the element has some effects on plant metabolism, such as the induction of disease resistance and allocation of resources for the synthesis of defense compounds and other secondary metabolisms. This may result in the plant having a higher energy expenditure to maintain these metabolisms and promote the supposed decreases in productivity observed in some cases (DÉLANO-FRIER et al., 2004). This may explain the downward trend in productivity, witnessed in the present study, with higher doses of silicon available to the seed.

Although silicon is not considered an essential element for plants, this work showed that its use in maize cultivation leads to an increase in crop productivity. Although grain gain has not been observed, this increase in productivity can be explained by the beneficial effects of silicon on some important production components, such as the spike diameter, number of rows per spike, and number of grains per row. The effects of these components on production justifies the gain in productivity with an increase in the silicon dose.

\section{CONCLUSIONS}

There were no effects of the foliar application of potassium silicate on the yield and yield components of the corn crop.

In acidic soil conditions, the use of phyllosilicate via seed coating increased the production components and yield of the corn crop.

\section{ACKNOWLEDGMENT}

This study was financed in part by Universidade Federal de Mato Grosso do Sul and the Coordenação de Aperfeiçoamento de Pessoal de Nível Superior - Brasil (CAPES) - Finance Code 001.

\section{REFERENCES}

COSKUN, D. et al. The role of silicon in higher plants under salinity and drought stress. Frontiers in Plant Science, v. 7, n. 1072, p. 1-7, 2016.

COSTA, R. R.; MORAES, J. C.; COSTA, R. R. Interação silício imidacloprid no comportamento biológico e alimentar de Schizaphis graminum (Rond.) (Hemiptera: Aphididae) em plantas de trigo. Ciência e Agrotecnologia, v. 33, n. 2, p. 455-460, 2009.

DANTAS JÚNIOR, E. E. et al. Silicate fertilizer and irrigation depth in corn production. Revista Ceres, v. 60, n. 4 , p. $563-568,2013$

DÉLANO-FRIER, J. P. et al. The effect of exogenous jasmonic acid on induced resistance and productivity in amaranth (Amaranthus hypochondriacus) is influenced by environmental conditions. Journal of Chemical Ecology, v. 30, n. 5, p. 1001-1034, 2004.

FERREIRA, D. F. SISVAR - Sistema de análise de variância. Versão 5.3. Lavras, 2010.

FREITAS, L. B. et al. Adubação foliar com silício na cultura do milho. Revista Ceres, v. 58, n. 2, p. 262$267,2011$.

GUNES, A. et al. Influence of silicone on sunflower cultivars under drought stress, ingrowth, antioxidante mechanisms, and lipid peroxidation. Soil Science and Plant Analysis, v. 39, n. 13, p. 1885-1903, 2008.

LESSA, B. F. T. et al. Physiological maturation in seeds of sweet sorghum for foliar fertilisation with silicate. Revista Caatinga, v. 30, n. 3, p. 718-729, 2017.

MA, J. F.; YAMAJI, N. Silicon uptake and accumulation in higher plants. Trends in Plant Science, v.11, n. 8, p. 392-397, 2006.

MENDES, L. D.; SOUZA, C. H. E.; MACHADO, V. N. Adubação com silício: influência sobre o solo, 
planta, pragas e patógenos. Cerrado Agrociências, v. 2, n. 2, p. 51-63, 2011.

NOGUEIRA, N. O. et al. Influência da aplicação de dois resíduos industriais nas propriedades químicas de dois solos cultivados com café arábica. Revista Ciência Agronômica, v. 43, n. 1, p. 11-21, 2012.

OLIVEIRA, S. de. et al. Tratamento de sementes de arroz com silício e qualidade fisiológica das sementes. Revista de Ciências Agrárias, v. 39, n. 2, p. 202-209, 2016.

PEREIRA, H. S. et al. Avaliação de fontes e extratores de silício no solo. Pesquisa Agropecuária Brasileira, v. 42, n. 2, p. 239-247, 2007.

SHI, X. H. et al. Effect of Si on the distribution of $\mathrm{Cd}$ in rice seedlings. Plant and Soil, v. 272, n. 1-2, p. 53-60, 2005.

SOUSA, R. S. et al. Cytological aspects of the infection process of Pyricularia oryzae on leaves of wheat plants supplied with silicon. Tropical Plant Pathology, v. 38, n. 6, p. 472-477, 2013.

SOUSA, J. V. et al. Silicato de potássio via foliar no milho: fotossíntese, crescimento e produtividade. Bioscience Journal, v. 26, n. 4, p. 502-513, 2010.

SOUSA, R. T. X.; KORNDÖRFER, G. H.; WANGEN, D. R. B. Aproveitamento de silício proveniente de escória siderúrgica por cultivares de cana-de-açúcar. Bragantia, v. 69, n. 3, p. 669-676, 2010 .

STOCCO, F. C. et al. Uso de escórias de siderurgia na produção de material seca e perfilhamento de duas gramíneas do gênero Brachiaria em um Latossolo Vermelho-Amarelo. Bioscience Journal, v. 26, n. 2, p. 240-248, 2010.

TEODORO, P. E. et al. Desempenho de híbridos de milho sob aplicação foliar de silício no cerrado sulmato-grossense. Bioscience Journal, v. 30, n. 3, p. 224-231, 2014. 